\title{
Behavior of Methylparaben in Emulsified Cosmetics Containing Powder
}

\author{
Masumi Takei, Hideto Hayashi, Takamasa Atsumi, \\ Kenichi Sakon, Kazushige Suzuki
}

\begin{abstract}
The emulsified cosmetics containing powder are composed of such complex systems that their antimicrobial activity often becomes a problem. First, we investigated the behavior of methylparaben (MP) in these systems to estimate the concentration of the active form of parabens.

Adsorption of MP by powder was expressed as a linear function of the initial concentration of MP $\left(\mathrm{C}_{0}\right)$ when the powder content was constant.

In the system containing powder and surfactant, the concentration of free MP in the aqueous phase (C3) was $62-65 \%$ of $\mathrm{C}_{\mathrm{O}}$.

In a model emulsion containing powder, the corresponding value (C5) was $20 \sim 27 \%$ of $\mathrm{C}_{0}$. In this system, the free MP in the aqueous phase before the powder addition was considered to be mainly adsorbed by powder.
\end{abstract}

\section{1. 緒 言}

化粧品には微生物污染を防ぐため，防腐剤が添加され る。パラベン類は比較的安全性の高い防腐剂としてよく 使用されるが，ある種の界面活性剤，高分子化合物，樹 脂や粉体などにより不活化されるといわれている。

従って,パラベン類を用いて防腐系を組む際に,それら の化粧品中に和ける活性型濃度を推測して使用量を決定 することが必要となる。防腐剂の活性型濃度は, 水相中 に freeな状態で存在する非解離型濃度と報告され1) 10), すでに非イオン性界面活性剤によるブチルパラベンの可 溶化 ${ }^{11)}$, o/w 型エマルション中でのメチルパラベンの 分配 ${ }^{12)}$ について報告がなされている。

加壳て，粉体を配合した乳化型化粧品は，系の複雑さ から，抗菌活性が問題となる。そこで我々は，この系に

(侏) ノビア滋賀中央研究所；滋賀県八日市市岡田町 $112-1$

NOEVIR Co. Ltd. Shiga Central Research Laboratory; 112-1 Okada cho, Youkaichi, Shiga Pref.
和けるパラベン類の活性型濃度を推測するため, すずメ チルパラベン (MP) の挙動を検討した。

\section{2. 実 験}

\section{1 試料}

$\mathrm{MP}$, ソルビタンモノラウレート, ポリオキシエチレ ン $(20 モ ル)$ ソルビタンモノステアレートは, 半井化学 試薬 1 級のものを使用した。タルク EP-1（東色ピグメ ント), タルクハイフィラー\#-13 (松村産業), カオリン ASP-170 (エンゲルハード)，テトラー2-エチルヘキサン 酸ペンタエリスリトール(日光ケミカルズ), スクワラ ン (日光ケミカルズ), ホホバ油 (香栄興業) は化粧品 用原料を使用した。

\section{2 平衡透析}

平衡透析は, 平衡透析用セル(アクリル樹脂製, 内容 量 $52 \mathrm{~m} \ell)$ を用い, 山口らの方法 ${ }^{111}$ に従って, $25^{\circ} \mathrm{C}$ で振 とう（87rpm，60時間）して行った。

\subsection{Pの定量}

MP の定量は，256nm に括けるUV吸収を測定するこ 
とにより行った。粉体添加の系に打ける MPの定量につ いては, $\mathrm{pH}$ 変化による MP の解離の影響を考慮し, $\mathrm{pH}$ 之解離定数から算出した。

\subsection{P の粉体による吸着}

2.4.1 粉体量一定のときの, 初濃度の影響

体質顔料であるタルク EP-1, タルクハイフィラー \#-13，カオリンASP-170 を用い，粉体添加量を 10.0 $(\mathrm{w} / \mathrm{v}) \%$ とし，MP の初濃度を 0 0.3(w/v)\%の範 囲で変化させ, 吸着実験を行った。吸着実験は, MP 水 溶液に粉体を分散させ, $25^{\circ} \mathrm{C}$ で吸着が平衡に達するま で振とう（87rpm）し, ろ過して粉体を除去した後, 未 吸着の MP 濃度を定量することにより行った。同時に， 同液の $\mathrm{pH}$ による影響も検討した。

2.4.2 初濃度一定のときの, 粉体量の影響

MP の初濃度を $0.1(\mathrm{w} / \mathrm{v}) \%$ とし, 粉体量を 0 20 $(\mathrm{w} / \mathrm{v}) \%$ まで变化させ，2.4.1 と同様に吸着実験を行 った。

\section{5 粉体分散および界面活性剂ミセル系における M Pの挙動の検討}

2.5.1 粉体, 界面活性剂量一定のときの, 初濃度の 影響

ポリオキシェチレン (20モル) ソルビタンモノステア レート $1.0(\mathrm{w} / \mathrm{v}) \%$ を含む $\mathrm{MP}$ 水溶液にタルク $\mathrm{EP}-1$ を 10.0 (w/v)\%となるように分散させ，2.4.1 と同様 に吸着実験を行った。ろ過して粉体を除去した後, 平衡
透析法により, 水相中フリ一の MP 濃度と, 界面活性阂 ミセルに取り込まれた MP 濃度を求めた。同様に粉体を 含まない系についても実験した。

2.5.2 初濃度・界面活性剂量一定のときの, 粉体量 の影響

MP の初濃度を 0.1 (w/v) \%, ポリオキシエチレン (20モル) ソルビタンモノステアレート濃度を $1.0(\mathrm{w} / \mathrm{v})$ \%とし，タルク EP-1 添加量を変えて吸着実験を行い，

2.5 .1 と同様に実験を行った。

\section{6 粉体を分散したエマルションモデルにおける M $\mathrm{P}$ の挙動の検討}

2.6.1 粉体量一定のときの初濃度の影響

Table.-1 に示した処方でェマルションモデルを調製 し、タルク EP-1を10.0（w/v)\%となるように分散さ

Table-1 エマルションモデルの処方

\begin{tabular}{|c|c|c|}
\hline 成 & 含量 & $(w / v) \%$ \\
\hline \multicolumn{2}{|c|}{ P.O.E.(20)ソルビタンモノステアレート } & 3.8 \\
\hline \multicolumn{2}{|c|}{ ソルビタンモノラウレート } & 1.2 \\
\hline \multicolumn{3}{|c|}{ テトラー2-エチルへキサン酸 } \\
\hline \multicolumn{2}{|c|}{ ペンタェリスリトール } & 3.0 \\
\hline \multicolumn{2}{|c|}{ スクワラン } & 0.1 \\
\hline \multicolumn{2}{|c|}{ ホホバ油 } & 0.1 \\
\hline \multicolumn{2}{|l|}{ MP } & $0 \sim 0.3$ \\
\hline
\end{tabular}

精慗水で $100.0 \mathrm{~m} \ell$ とする。

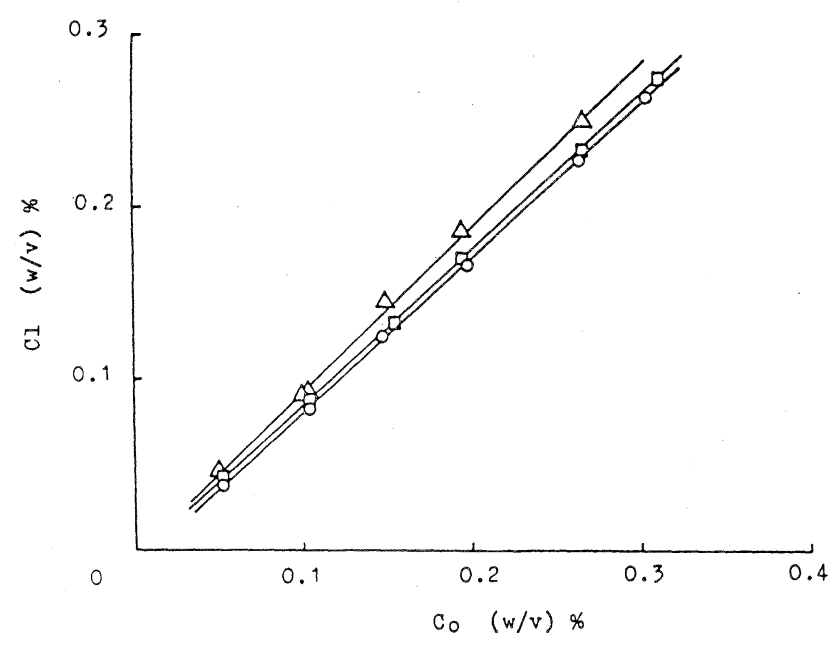

Fig. -1 粉体によるMPの吸着——初濃度の影響

$\bigcirc$; Talc EP-1, $\square$; Talc HF \#-13,

$\triangle$; Kaolin ASP-170. 粉体量 $=10.0$

$(\mathrm{w} / \mathrm{v}) \%$. 
せ，2.4.1 と同様に吸着実験を行った後，静置して粉体 を沈降させ，平衡透析を行って水相中フリーの MP 濃度 を求めた。同様に，粉体を含まないエマルションモデル においても, フリーの MP 濃度を求めた。

2.6.2 初濃度一定の之きの粉体量の影響

MP の初濃度を $0.2(\mathrm{w} / \mathrm{v}) \%$ としてエマルションモ デルを調製し，タルク EP-1 添加量を変えて吸着実験を 行い, 2.6 .1 と同様にフリーの MP 濃度を求めた。

\section{3. 結果と考察}

\section{1 粉体によるMPの吸着}

3.1 .1 粉体量一定のときの初濃度の影響

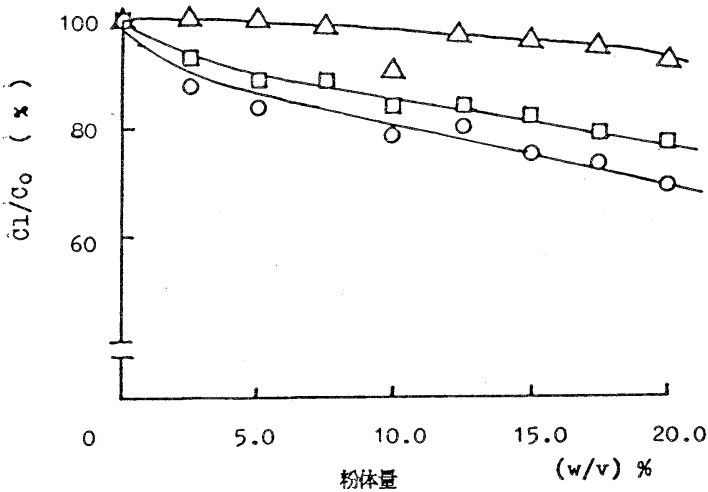

Fig.-2 粉体によるMPの吸着一一粉体量の影響 $\bigcirc$; Talc EP-1, $\square$; Talk HF \#-13, $\triangle$; Kaolin ASP-170. $\mathrm{C}_{0}=0.1(\mathrm{w} / \mathrm{v}) \%$.

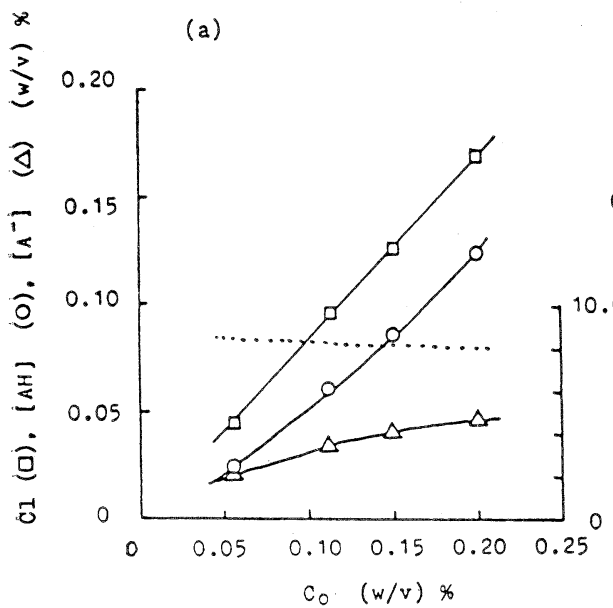

Fig. -1 は，粉体に吸着されない $\mathrm{MP}$ 濃度 $\mathrm{C} 1$ と $\mathrm{MP}$ の初濃度 $\mathrm{C}_{0}$ との関係について示している。

$\mathrm{C} 1$ と $\mathrm{C}_{0}$ の間には良い直線関係が認められる。タルク $\mathrm{EP}-1$, タルクハイフィラー\#-13, カオリン ASP-170 について得られた回帰直線は, 各々, $\mathrm{C} 1=0.8961 ・ \mathrm{C}_{0}-$ $9.156 \times 10^{-3}(\mathrm{r}=0.9998), \mathrm{C} 1=0.8950 \cdot \mathrm{C}_{0}-5.204 \times$ $10^{-3}(\mathrm{r}=0.9999), \mathrm{C} 1=0.9494 \cdot \mathrm{C}_{0}-1.487 \times 10^{-3}(\mathrm{r}=$ 0.9993)，(危険率 $\alpha=1 \%$ で有意）であった。以上のよ らに, 一定量の粉体による MP の吸着は, 初濃度の 1 次 式となる。

\section{1 .2 初濃度一定のときの粉体量の影響}

Fig. -2 は， $\mathrm{C} 1 / \mathrm{C}_{0}$ と粉体量の間に得られる関係を示 しだ。

タルク $\mathrm{EP}-1$, タルクハイフィラー\#-13, カオリン ASP-170 について得られた回帰曲線は，粉体量を $x$ と して各々, $\mathrm{C} 1 / \mathrm{C}_{0}=\exp (-0.01547 \cdot x+4.546)(\mathrm{r}=$ $-0.9568), \mathrm{C} 1 / \mathrm{C}_{0}=\exp (-0.01141 \cdot x+4.571)(\mathrm{r}=$ $-0.9726), \mathrm{C} 1 / \mathrm{C}_{0}=100 \exp \left(-1.551 \times 10^{-4} \cdot x^{2}-4.620\right.$ $\left.\times 10^{-4} \cdot x-3.438 \times 10^{-4}\right),(\mathrm{r}=-0.9924)(\alpha=1 \%$ で有 意) で, 酸処理しているタルク EP-1 と, 酸処理してい ないタルクハイフィラー\#-13による吸着挙動は同じで, $2.5(\mathrm{w} / \mathrm{v}) \%$ 以下で変曲点があり, $2.5(\mathrm{w} / \mathrm{v}) \%$ 以上で は直線的に減少していた。カオリンASP-170 はほとん ど吸着を示さなかった。

\section{$3.1 .3 \mathrm{pH}$ の影響}

タルク EP-1, カオリン ASP-170 を分散した MP 水

\section{(b)}

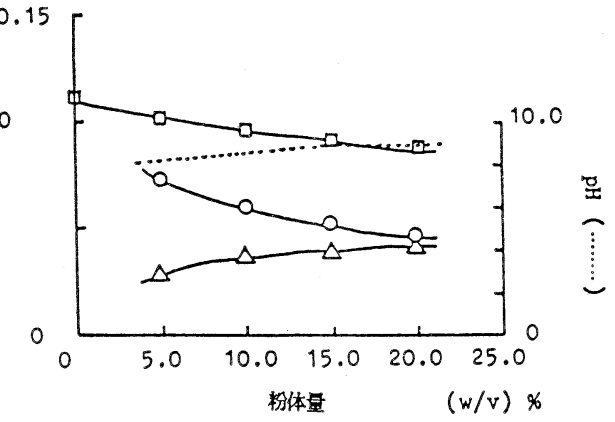

Fig. -3 タルク $\mathrm{HF}$ - 13 による $\mathrm{MP}$ の吸着一 $\mathrm{pH}$ の影響

(a) 非吸着の $\mathrm{MP}(\mathrm{Cl})$, 非解離型の $\mathrm{Cl}([\mathrm{AH}])$, 解離型の $\mathrm{MP}\left(\left[\mathrm{A}^{-}\right]\right)$と $\mathrm{C}_{0}$ の関係

(b) $\mathrm{Cl},[\mathrm{AH}],\left[\mathrm{A}^{-}\right]$と粉体量の関係 


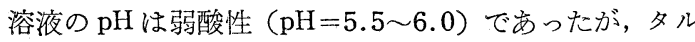
クハイフィラー \#-13 を分散したものでは $\mathrm{pH}$ が $8 \sim 9$ に上昇し，MPの解離を考学る必要が生じた。

Fig. -3 に示すように，粉体に吸着されない MP 濃度 $\mathrm{C} 1$ は非解離型および解離型濃度 $[\mathrm{AH}],\left[\mathrm{A}^{-}\right]$の和とな り，[AH]のみが活性型濃度となる。 $\mathrm{MP}$ の解離定数を $\mathrm{K}_{\mathrm{a}}$ とすると, $[\mathrm{AH}]=\mathrm{C} 1\left[\mathrm{H}^{+}\right] /\left(\mathrm{K}_{\mathrm{a}}+\left[\mathrm{H}^{+}\right]\right),\left[\mathrm{A}^{-}\right]=$ $\mathrm{C} 1 \cdot \mathrm{K}_{\mathrm{a}} /\left(\mathrm{K}_{\mathrm{a}}+\left[\mathrm{H}^{+}\right]\right)\left(\left[\mathrm{H}^{+}\right]\right.$は水素イオン濃度) と表す ことができ, $\mathrm{pH}$ と $\mathrm{K}_{\mathrm{a}}=3.162 \times 10^{-9}$ 13) とから求める ことができる。以上のよらに， $\mathrm{pH}$ が上昇する場合に は，MP の解離による不活化の影響を考慮しなければな らない。以下の実験では，吸着量が多く $\mathrm{pH}$ 変化のない タルク EP-1 を用いた。

\section{2. 粉体分散および界面活性剂ミセル系における M Pの挙動}

3.2.1 粉体・界面活性剂量一定時の MP の初濃度の 影響

粉体に吸着されないMP 濃度 C2 特よび，ミセルに取 り込まれていないフリーの MP 濃度 C3 $2 \mathrm{MP}$ の初濃度 $\mathrm{C}_{0}$ との関係, 粉体無添加の系に尘㺭るC3 $2 \mathrm{C}_{0}$ の関係 を Fig. -4 に示した。

いずれについてる良い直線関係が得られ，回帰直線は， 粉体添加の系では， $\mathrm{C} 2=0.8993 \cdot \mathrm{C}_{0}+2710 \times 10^{-3}(\mathrm{r}=$ $0.9991), \mathrm{C} 3=0.6577 \cdot \mathrm{C}_{0}-3.573 \times 10^{-3}(\mathrm{r}=0.9979)$, 粉体無添加の系では, $\mathrm{C} 3=0.7486 \cdot \mathrm{C}_{0}-8.273 \times 10^{-3}$ (r $=0.9996)(\alpha=1 \%$ で有意) であった。

C3 と, 界面活性剤ミセルに可溶化された MP 濃度 C4

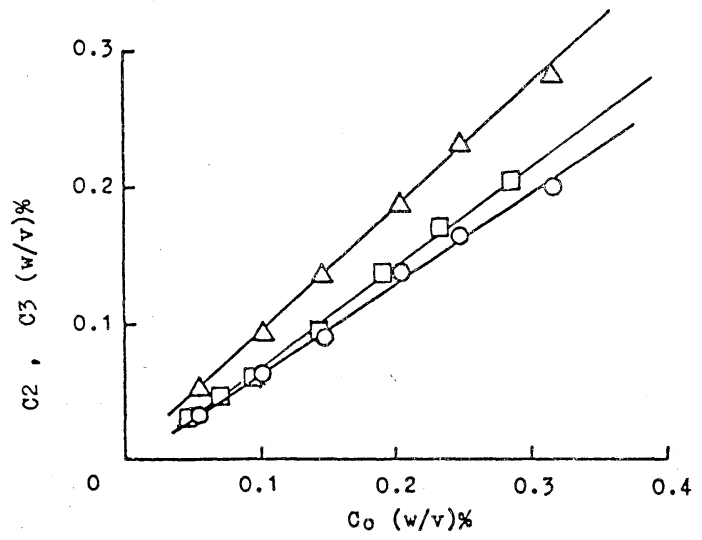

Fig. -4 粉体および界面活性剤存在下における MPの挙動——初濃度の影響 $\bigcirc$; 粉体添加時の C $3, \triangle$; 粉体添加時の $\mathrm{C} 2, \square$; 粉体無添加時の C3 粉体量 $=10.0(\mathrm{w} / \mathrm{v}) \%$.
について, Langmuir's plotsを行った。結果を Fig.ーら に示した。粉体無添加の系についても併せて示した。

1/C3 と 1/C4 の間には良い直線関係が得られ，この 系に和いても界面活性剂による MP の可溶化は Langmuir 型の吸着に従うことがわかる。この場合の $\mathrm{K}_{1} \mathrm{~K}_{2}$ : 值は 0.5013 で, 粉体無添加の場合の 0.6519 に比べや.

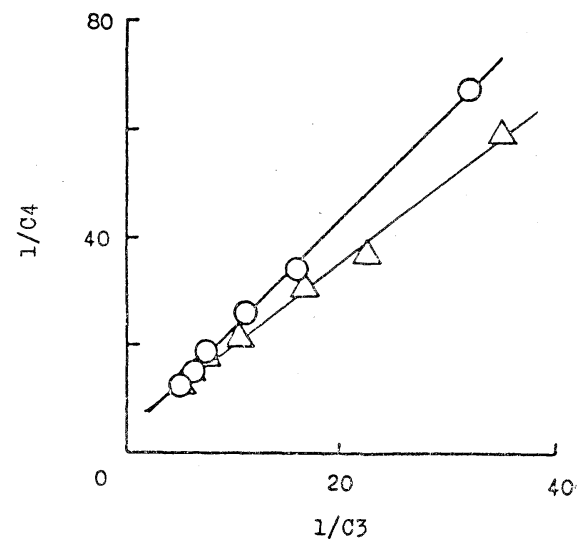

Fig. -5 粉体および界面活性鼡存在下における MPの挙動—Langmuir's plots.

$\bigcirc$; 粉体添加時の Langmuir's plots.

$\triangle$; 粉体無添加時の Langmuir's plots。

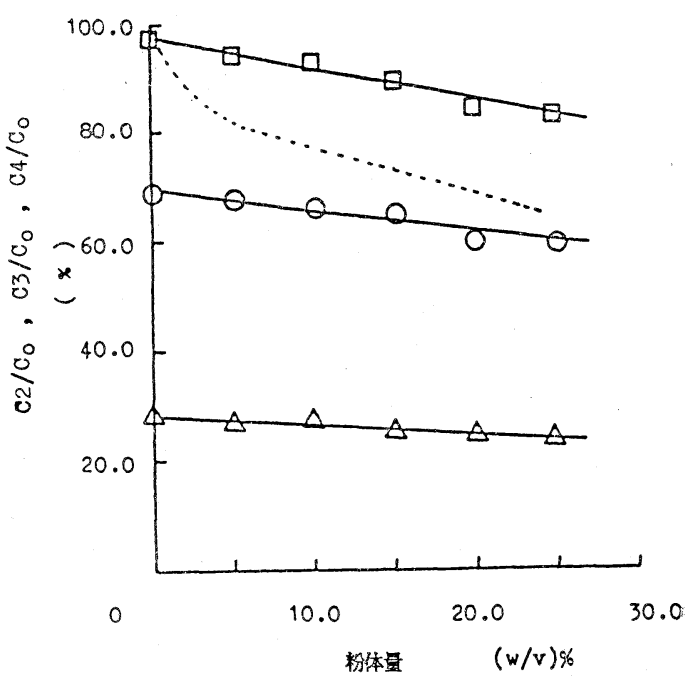

Fig. -6 粉体および界面活性剤存在下における MP の挙動——粉体量の影響 界面活性剤存在下における， $\mathrm{O} ; \mathrm{C} 3 / \mathrm{C}_{0}$, $\triangle ; \mathrm{C} 4 / \mathrm{C}_{0}, \square ; \mathrm{C} 2 / \mathrm{C}_{0}, \cdots \cdots ; \mathrm{MP}$ 水溶 液に粉体を添加した時の $\mathrm{C} 1 . \mathrm{C}_{0}=0.1$ (w/v) $\%$. 
や小さくなって招り, 界面活性剤による可溶化の程度 は，粉体添加によりやや小さくなる。

3.2.2 MP の初濃度, 界面活性剂量一定のときの, 粉体量の影響

Fig. -6 に, MP の初濃度, 界面活性剂量を一定とし, タルク $\mathrm{EP}-1$ 添加量を変化させ, $\mathrm{C} 2 / \mathrm{C}_{0}, \mathrm{C} 3 / \mathrm{C}_{0}, \mathrm{C} 4 /$ $\mathrm{C}_{0}$ を粉体量に対して各々プロットした結果を示す。

各々について得られた回帰曲線は，粉体量を $x$ とし $\tau, \mathrm{C} 2 / \mathrm{C}_{0}=\exp \left(-6.193 \times 10^{-3} \cdot x+4.244\right)-0.1943$ • $x+28.20, \mathrm{C} 3 / \mathrm{C}_{0}=\exp \left(-6.193 \times 10^{-3} \cdot x+4.244\right)(\mathrm{r}=$ $-0.9731), \mathrm{C} 4 / \mathrm{C}_{0}=-0.1943 \cdot x+28.20(\mathrm{r}=-0.9736)$ （ $\alpha=1 \%$ で有意）であった。この系に执いても，MP のタルク EP-1 による吸着挙動には大きな変化はみら れないが，一定濃度の MP に対し，粉体量を変化させ たとき，MP の吸着は界面活性剂無添加時の約 40\% 飞 抑制されていた。 $\mathrm{C} 4 / \mathrm{C}_{0}$ は粉体量に対しほぼ 1 次関数的 に減少していた。3.2.1 和よびこの結果より, 界面活性 剤が粉体に吸着されるため, MP のミセル中への取り込 みが減少するものと考光られる。

Fig.-4 に示した $\mathrm{C} 3 ， \mathrm{C}_{0}$ の関係と, Fig.-6 の C3/C 值とから，この系では，粉体による吸着と界面活性剂侣 よる可溶化の結果, 水相中にフリーで存在する MP 濃度 は，初濃度の $62 \sim 65 \%$ であった。をた， $\mathrm{C} 4 / \mathrm{C}_{0}$ の減少 よりも， $\mathrm{C} 3 / \mathrm{C}_{0}$ の減少の方が大きいことから，界面活性 剤ミセル系に括いては，主に水相中のミセルに取り込ま れていない MP が粉体に吸着されると考光られる。

\section{3 粉体を分散したエマルションモデルにおけるM Pの挙動}

3.3.1 粉体量一定のときの初濃度の影響

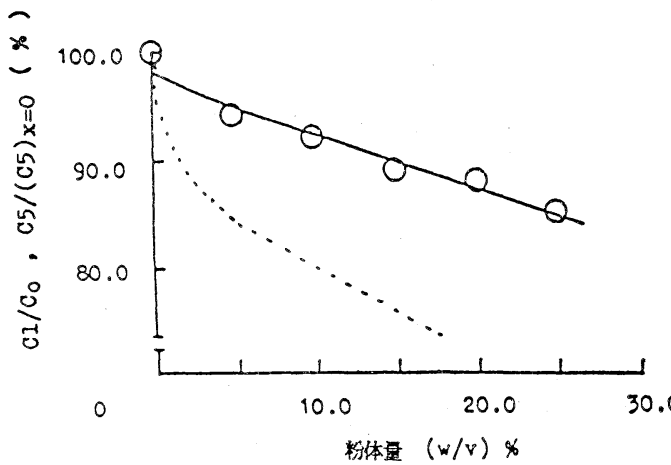

Fig. -7 は，粉体を一定量添加したエマルションモデ ルに叔りる, 水相中のフリーの MP 濃度 $\mathrm{C} 5$ と, 初濃度 $\mathrm{C}_{0}$ との関係を示す。粉体無添加の系についても併せて示 した。

この系に执いても $\mathrm{C} 5$ と $\mathrm{C}_{0}$ の間には良い直線関係が

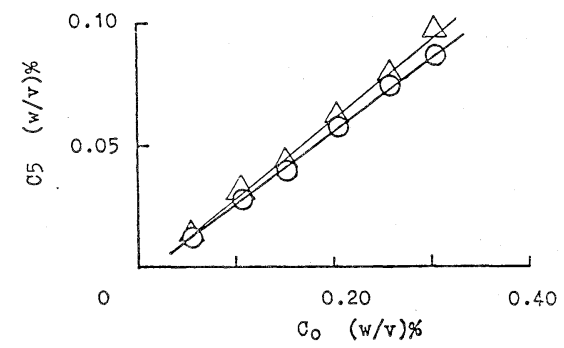

Fig.-7 粉体添加および無添加のエマルションモ デルにおける MP の挙動—初濃度の影響 $\bigcirc$; 粉体添加時の $\mathrm{C} 5, \triangle$; 粉体無添加時 の $\mathrm{C} 5$, 粉体量 $=10.0(\mathrm{w} / \mathrm{v}) \%$.

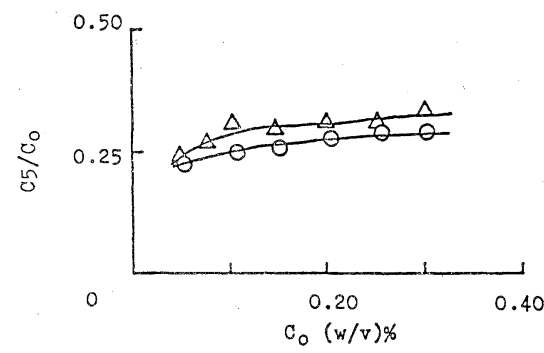

Fig.-8 エマルションモデルにおける $\mathrm{C} 5 / \mathrm{C}_{0}$ 值に 対する粉体添加の影響

$\bigcirc$; 粉体添加時, $\triangle$; 粉体無添加時.

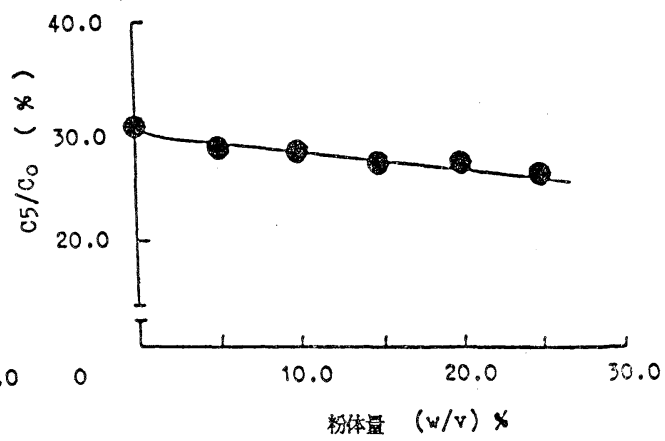

Fig. -9 粉体を添加したェマルションモデルにおけるMPの挙動——粉体量の影響 $\bigcirc$; 粉体添加および無添加時の $\mathrm{C} 5$ の比, C5/(C5) $x=0, \cdots \cdots ; \mathrm{MP}$ 水溶液 に粉体を添加した時の $\mathrm{C} 1 / \mathrm{C}_{0}$.

; 粉体添加時の $\mathrm{C} 5 / \mathrm{C}_{0}, \mathrm{C}_{0}=0.2(\mathrm{w} / \mathrm{v}) \%$. 
得られ, 回帰直線は C5 $=0.2989 \cdot \mathrm{C}_{0}-5.307 \times 10^{-3}(\mathrm{r}$ $=0.9990)(\boldsymbol{x}=1 \%$ で有意) で, 直線の傾きは粉体無添 加の場合の約 $90 \%$ となっていた。粉体添加, 無添加の 各場合について， $\mathrm{C} 5 / \mathrm{C}_{0}$ を $\mathrm{C}_{0}$ に対してプロットすると， Fig. -8 に示す結果を得た。

粉体の添加により，C5/C 0 值は粉体無添加時の約 $90 \%$ となって抢り，水相中に残存するフリーの MP 濃度は， 初濃度の 20 2 $27 \%$ であった。

3.3.2 初濃度一定のときの粉体の影響

次に, MP の初濃度が一定のエマルションに和いて, 粉体添加抢よび無添加時の $\mathrm{C} 5$ の比, C5/(C5) $x=0$ と, 粉 体量との関係, 粉体添加時の $\mathrm{C} 5 / \mathrm{C}_{0}$ と粉体量との関係 をFig.-9に示した。

各々に対する回帰曲線は，粉体量を $x$ として，C5/ (C5) $)_{x=0}=\exp \left(-5.949 \times 10^{-3} \cdot x+4.588\right), \mathrm{C} 5 / \mathrm{C}_{0}=\exp$ $\left(-5.949 \times 10^{-3} \cdot x+3.397\right)(\mathrm{r}=-0.9744)(\alpha=1 \%$ で 有意)であった。エマルションモデルに和いても,タル ク EP-1による MP の吸着挙動は同様であったが，粉体 量と吸着量の関係をみると, 吸着は MP 水溶液の場合の ほ涪 38\% 飞抑制されていた。また，C5/C よりも C5/ (C5) $x=0$ の方が粉体添加により影響を受けるので，主に 水相中に存在するフリーの MP が粉体に吸着される, と 考光らる。

\section{参考文献}

1) T. Shimamoto, Y. Ogawa and N. Ohkura,
Chem. Pharm. Bull., 21, 316 (1973)

2) M. G. deNaVarre and H. E. Bailey, J. Soc. Cosmet. Chem., 7, 427 (1956)

3) H.S.Bean and S.M.Heman-Ackah, J.Pharm. Pharmacol., 16, suppl. 58T (1964)

4) S.M.Heman-Ackah and G.H.Konning, ibid., 19, suppl. 189S (1967)

5) O.Rahn and J.E.Conn, Ind. Eng. Chem., 36, 185 (1944)

6) E.R.Garrett and O.R.Woods, J. Am.Pharm. Asso. Sci. Ed., 42, 736 (1953)

7) M.G.deNaverre, J. Soc. Cosmet. Chem., 8, 68 (1957)

8) S.M.Blaug and S.S.Ahsan, J. Pharm. Sci., 50, 138 (1961)

9) A. G. Mitchell, J. Pharm. Pharmacol., 16, 533 (1964)

10) N.K.Patel and J.M.Romanowski, J. Pharm. Sci., 59, 372 (1970)

11）山口道廣, 浅賀良雄, 田中宗男, 光井武夫, 太田 三郎，粧技誌15，372 (1981)

12）小川泰亮, 島本次雄, 神代良明, 粧 技誌 12,60 (1977)

13) T.R. Aalto, (M.C. Firman and N. E. Rigler,) J. Am. Pharm. asso. Ed. 42, 449 (1953)

(昭和 60 年 2 月 7 日受理) 